\title{
THE IMPORTANCE OF SOCIO-CULTURAL FACTORS IN MARKET SEGMENTATION: CAPPADOCIA EXAMPLE
}

\section{DOI: 10.17261/Pressacademia.2017.719 \\ RJBM- V.4-ISS.3-2017(18)-p.417-426}

\section{Emin Akkilic ${ }^{1}$, Volkan Ozbek ${ }^{2}$, Nilay Aldemir ${ }^{3}$}

${ }^{1}$ Balıkesir Üniversitesi, Burhaniye UBYO, Uluslararası Ticaret Bölümü, Balıkesir, Turkey. eakkilic@balikesir.edu.tr

${ }^{2}$ Balıkesir Üniversitesi, Burhaniye UBYO, Uluslararası Ticaret Bölümü, Balıkesir, Turkey. vozbek.@balikesir.edu.tr

${ }^{3}$ Balıkesir Üniversitesi, SBE, Uluslararası Ticaret ve Pazarlama Bölümü, Balıkesir, Turkey. nilayaldemir@gmail.com

\section{To cite this document}

Akkilic, M.E., V. Ozbek and N. Aldemir, (2017). The importance of socio-cultural factors in market segmentation: Cappadocia example Research Journal of Business and Management (RJBM), V.4, ISS.3, p.417-426.

Permemant link to this document: http://doi.org/10.17261/Pressacademia.2017.719

Copyright: Published by PressAcademia and limited licenced re-use rights only.

\begin{abstract}
Purpose- The main aim of this study is to reveal whether a different market segmentation is necessary for domestic and foreign tourists visiting a destination with different socio-cultural factors, and various motivations. In order to reach this aim, a field work was carried out on British, German and Turkish tourists visiting Cappadocia destination.

Methodology- Face-to-face survey method was used in the research. In the questionnaire there are demographic features and sociocultural factors which cause the preference of Cappadocia destination and expressions to measure motivational elements. The survey was conducted on 398 people who were identified by convenience sampling.

Findings- Research findings reveal that socio-cultural factors affecting British, German and Turkish tourists visits to Cappadocia are different from each other. Therefore, it appears that the British, German, and Turkish tourists differs in terms of the influence of family members, friends, specimens, and cultural reasons. Similar differences are seen on motivational factors affecting to choose Cappadocia. While domestic tourists express the reason of coming to this destination as "because it is fashion." British tourists state that they prefer this destination "because it is multi-cultural region." Germens enounce that they choose this destination "because of its local dishes".

Conclusion- As a result of the research, it has been revealed that tourists visiting Cappadocia destination with motivations and different socio-cultural factors can create different market segments in terms of tourism firms. The study was concluded with suggestions to academicians and practitioners.
\end{abstract}

Keywords: Market segmentation, motivation, culture, Cappadocia destination.

JEL Codes: L80, M31

\section{PAZAR BÖLÜMLENDIRMESINDE SOSYO-KÜLTÜREL FAKTÖRLERIN ÖNEMI: KAPADOKYA ÖRNEĞi}

\section{ÖZET}

Amaç- Bu araştırmanın temel amacı, farklı sosyo-kültürel etkenlerle ve farklı motivasyonlarla bir turizm destinasyonunu ziyaret eden yerli ve yabancı turistler için farklı bir pazar bölümlendirmesine ihtiyaç olup olmadığını ortaya koymaktır. Bu amaca ulaşmak için Kapadokya destinasyonunu ziyaret eden İngiliz, Alman ve Türk turistler üzerinde bir saha çalışması gerçekleştirilmiştir.

Yöntem- Araştırmada yüz yüze anket yöntemi kullanılmıştır. Anket formunda demografik özellikleri ve Kapadokya destinasyonunun tercih edilmesine neden olan sosyo-kültürel faktörler ile motivasyonel unsurları ölçmeye yönelik ifadeler bulunmaktadır. Uygulama, kolayda örnekleme yöntemiyle belirlenen 398 kişi üzerinde gerçekleştirilmiştir.

Bulgular- Araştırma bulguları, İngiliz, Alman ve Türk turistlerin Kapadokya'yı ziyaret etmelerinde etkili olan sosyo-kültürel faktörlerin birbirinden farklı olduğunu ortaya koymaktadır. Buna göre, İngiliz, Alman ve Türk turistlerin aile bireylerinin, arkadaşların, örnek alınan ve özenilen kişilerin ve kültürel nedenlerin etkisi bakımından farkılaştığı görülmektedir. Benzer farklılıklar Kapadokya’yı tercih etmede etkili olan motivasyonel faktörlerde de görülmektedir. Yerli turistler bu destinasyona en çok "moda olduğu için" geldiklerini ifade ederken, İngilizler en çok "çok kültürlü bölge" olduğu için tercih ettiğini ifade etmiştir. Almanlar ise, en çok "yerel mutfak" dolayısıyla bu destinasyonu tercih ettiklerini belirtmiştir.

\footnotetext{
- Bu araştırma Balıkesir Üniversitesi Bilimsel Araştırma Projeleri Birimi tarafından desteklenmiştir. Bu araştırma Global işletme Araştırmaları Kongresi'nde (2425 Mayıs 2017) Bildiri olarak sunulmuştur.
} 
Sonuç- Araştırma sonucunda, farklı sosyo-kültürel faktörlerin etkisiyle ve değişik motivasyonlarla Kapadokya destinasyonunu ziyaret eden turistlerin, turizm işletmeleri açısından farklı pazar bölümleri oluşturabileceği ortaya çıkmıştır. Çalışma, akademisyenlere ve uygulayıcılara önerilerde bulunularak tamamlanmıştır.

Anahtar Kelimeler: Pazar bölümlendirmesi, Motivasyon, Kültür, Kapadokya destinasyonu.

JEL Kodları: L8, M31

\section{GiRiş}

İnsanlar, yaşamlarını sürdürebilmeleri için hem biyolojik olarak hem de çevresel faktörlerin etkisiyle birçok ürüne ihtiyaç duyar. Ancak, kişilerin ihtiyaçlarının teminindeki istekleri ve davranış biçimleri farklılık gösterebilmektedir. Bölgesel pazarlardan ulusal pazarlara, ulusal pazarlardan uluslararası pazarlara doğru gidildikçe farklı özelliklere sahip tüketicilerin sayısında bir artışın olması beklenen bir durumdur. İşletmelerin farklı özelliklere sahip ve farklı tüketim alışkanlığı olan tüketiciler için pazar bölümlendirmesine gitmesi, bu tüketicileri işletmeye çekebilmek için gereklidir. Pazar bölümlendirme, tüm sektörlerde kullanılabilen faydalı bir strateji olmakla birlikte, müşterileri birbirinden son derece farklı olabilen turizm sektörü için daha büyük bir önem arz etmektedir.

Farklı turizm ürünlerinin varlığı bunlara yönelecek mevcut potansiyel talebin ayrı ayrı belirlenmesini yani pazarın bölümlendirilmesini gerektirir. Bölümleme, en az maliyetle, en yüksek verim ve kâr koşulları içinde tüketicileri seçmek ve onlara ürünlerini kabul ettirip, onları tatmin etmek demektir. Pazar bölümlendirme, bir pazarın aynı özellikleri taşıyan alt gruplara ayrılması işlemidir. Burada amaç, pazarı oluşturan turistlerden, istek ve ihtiyaçları, satın alma davranışları ve turizm eğilimleri benzer olan turist gruplarını bir araya getirmektir. Hedef turist grubunun belirli özellikleri ne kadar iyi biliniyorsa yürütülecek reklam, tanıtım ve satış geliştirme işlemleri o ölçüde etkili olur (Hayta, 2008, s.34-35). Doğru tespit edilen turist profili sayesinde destinasyonu ziyaret eden turistlerin homojen gruplara ayrılarak pazar bölümlendirmesinin gerçekleştirilmesi ve belirlenen her bir pazar bölümüne ilişkin istek ve beklentilere uygun turistik ürünün sunulması mümkün olabilecektir. Pazarlama açısından önemli bir kavram olması ve destinasyonlarda gerçekleştirilen pazarlama faaliyetlerine önemli katkılar sağlamasına rağmen ülkemizde destinasyon bazında turist profili belirleme ve pazar bölümlendirme çalışmaları yeterli değildir (Çokişler ve Türker, 2015, s.33-34).

Etkili bir pazar bölümlendirmesinin yapılabilmesi için genel kabul görmüş kriterler bulunmaktadır. Bu kriterlerden bazıları; pazarın ölçülebilir, ulaşılabilir, belirli bir büyüklükte ve anlamlı olması gerekliliğidir (Yükselen, 2012, s.192-193). Ölçümü kolay olmasından dolayı, demografik ölçütler (cinsiyet, gelir, yaş ve eğitim gibi) sıklıkla kullanılan pazar bölümlendirme özellikleridir. Ancak, Tüketicilerin genel ve gözlemlenebilen değişkenlere göre bölümlendirilmesi temelde bazı sorunları da beraberinde getirmektedir. Örneğin, artan ve giderek birbirine yaklaşan tüketici gelirlerine dayanarak tüketicilerin benzer harcama eğilimlerinde olacağını belirtmek çok doğru sonuçlar üretmekten uzak olabilir. Bu noktada, motivasyon gibi gözlemlenemeyen değişkenlere göre pazar bölümlendirmesi ön plana çıkmakta ve bu motivasyonların gerisinde yatan kültür etkeni büyük farklılıklar doğurabilmektedir (Nacar ve Uray, 2014, s.45).

Tüketici davranışlarındaki farklılıkların temel nedenleri arasında yer alan sosyo-kültürel faktörler ve motivasyon unsuru, tüketicilerin ürün tercihi yaparken farklı ürünler tercih etmesine ya da aynı ürünü farklı bir özelliğinden dolayı tercih etmesine neden olabilecektir. Turistik ürünlerin ya da destinasyonların tercih edilmesinde de beklenti bu yönde olacaktır (Iso-Ahola ve Allen, 1982; Lee, 2000; Uysal ve Li, 2008). Bu noktada, herhangi bir destinasyonun tercihinde etkili olan sosyokültürel ve motivasyonel faktörlerin neler olduğunun incelenmesi ve bu faktörlerin farklı pazar bölümleri oluşturmak için yeterli olup olmadığının belirlenmesi sektörel açıdan önemlidir. Bu bağlamda, bu çalışmanın temel amacı farklı sosyokültürel etkenler ve farklı motivasyonlarla bir turizm destinasyonunu ziyaret eden yerli ve yabancı turistler için farklı bir pazar bölümlendirmesine ihtiyaç olup olmadığını belirlemektir. Ayrıca, bu çalışma ile yerli ve yabancı turistlerin destinasyon seçimini yaparken sosyo-kültürel ve motivasyonel faktörlerin ne derecede etkisinde kaldığını ortaya koymak da hedeflenmiştir. Belirlenen bu amaçlara ulaşmak için Kapadokya destinasyonunu ziyaret eden İngiliz, Alman ve Türk turistler üzerinde bir uygulama gerçekleştirilmiştir.

Çalışmada öncelikle ilgili literatüre yönelik inceleme sunulmuş ve araştırma hipotezleri ortaya konmuştur. Ardından, yöntem bölümünde araştırmanın amacı, evreni ve örneklem hakkında bilgi verilmiş ve anket formunun tasarımı anlatılmıştır. Bulgular bölümünde, katılımcıların demografik profili hakkında bilgi verilmiş ve araştırma hipotezlerinin test bulguları sunulmuştur. Sonuç ve öneriler bölümünde ise, bulgulara yönelik değerlendirmelere yer verilmiş; akademisyen ve uygulayıcılara önerilerde bulunularak çalışma tamamlanmıştır.

\section{LITERATÜR ARAŞTIRMASI}

Turistler destinasyon seçimini yaparken, ekonomik, sosyo-kültürel, demografik özellikler gibi pek çok faktörün etkisinde kalırlar. Bu genel faktörler dışında, destinasyona özgü bazı çekici faktörlerin de gerek yerli, gerekse yabancı turistlerin satın alma davranışı üzerinde etkisi vardır (Demir, 2010, s.1042; Nakip, Varinli ve Gülmez, 2012, s.43-54; Gnoth, 1997, s.288). Bu 
noktada motivasyonel unsurlar ön plana çıkmaktadır. Bu bölümde, çalışmanın amacına yönelik olarak sosyo-kültürel faktörler ile motivasyon unsuruna ilişkin yapılan alan yazın çalışmalarına yer verilmiştir.

\subsection{Sosyo-Kültürel Faktörler}

Sektör ayrımı yapmaksızın, tüketicilerin satın alma davranışı üzerinde birçok faktörün etkisi olduğu bilinmektedir. Ülkelerin gelişmişlik düzeylerine göre farklılık olsa da, tüketicilerin satın alma davranışı üzerinde etkili olan faktörlerin başında ürünün fiyatının geldiği söylenebilir. Ancak, her zaman ve her üründe bu ifadeyi kullanmak doğru değildir. Çünkü bazı durumlarda ya da bazı ürünlerin satın alınmasında ürünün özellikleri, tüketicinin içinde bulunduğu sosyal yapı, ürüne olan ilgi, eğitim düzeyi ve kültür gibi faktörler fiyatın önüne geçebilmektedir. Yani, tüketiciler ürünün fiyatı dışında birçok faktörden etkilenebilmektedir. Tüketici davranışlarını etkileyen faktörler Şekil 1'de gösterilmiştir.

Tüketicilerin satın alma davranışları üzerinde etkisi olan önemli faktörlerden biri kültürdür. Bu faktör, alt kültür ve sosyal sınıf gibi tüketicinin satın alma davranışını etkileyen alt katmanlardan oluşur (Kotler ve Keller, 2006, s.174). Alt kültür, nüfus sayısındaki artışla birlikte kültürde bölgesel, dini, ırki ve benzeri alt katmanlar ve bu katmanlarda sayı artışını ortaya çıkarır. Sosyal sınıf ise aynı toplumsal saygınlığa sahip, birbirleriyle çok sıkı ilişkileri olan ve davranışsal beklentileri benzer olan kişilerin oluşturduğu bir sosyal yapı olarak ifade edilebilir (Tek, 1997, s. 198-199; Odabaşı ve Barış, 2002, s. 296).

\section{Şekil 1: Tüketici Davranışlarını Etkileyen Faktörler}

\begin{tabular}{|c|c|c|c|c|}
\hline Kültür & & & & \\
\hline \multirow{10}{*}{$\begin{array}{c}\text {-Kültür } \\
\text {-Alt kültür } \\
\text {-Sosyal sınıflar }\end{array}$} & Sosyal & Kișisel & & \\
\hline & \multirow{7}{*}{$\begin{array}{c}\text {-Referans } \\
\text { grupları } \\
\text {-Aile } \\
\text {-Rol ve statüler }\end{array}$} & \multirow{6}{*}{$\begin{array}{c}\text {-Meslek } \\
\text {-Ekonomik } \\
\text { durum } \\
\text {-Yaşam tarzı }\end{array}$} & Psikolojik & \multirow{5}{*}{ TÜKETICI } \\
\hline & & & \multirow{5}{*}{$\begin{array}{c}\text {-Motivasyon } \\
\text {-Algılama } \\
\text {-Öğrenme } \\
\text {-İnanç ve } \\
\text { tutumlar }\end{array}$} & \\
\hline & & & & \\
\hline & & & & \\
\hline & & & & \\
\hline & & & & \\
\hline & & -KIŞIIIK & & \\
\hline & & & & \\
\hline & & & & \\
\hline
\end{tabular}

Dış pazarı oluşturan turistlerin satın alma davranışlarının değişkenliği, iç pazarı oluşturan turistlere göre çok daha fazla ve karmaşık olabilmektedir. Dolayısıyla kişilerin içinde bulunduğu sosyo-kültürel durumları, ürünlerden beklentilerini farklılaştırmış, birbirinden farklı ve karmaşık yapılı davranışların ortaya çıkmasına neden olmuştur (Tayfun ve Yıldırım, 2010, s.43-46). Bu doğrultuda Akat (2003), ülkelerin kültürleri arasındaki farklılıkların, pazarlamadaki politikaları ve stratejileri çok açık bir şekilde etkilediğini, bu nedenle her ülkenin gelenek, görenek, tutum, alışkanlık, sanat, müzik gibi özelliklerinin küresel bazda incelenmesi gerektiğini vurgulamaktadır (Akat, 2003, s.5). Penaloza ve Gilly (1999) bu konuda yapmış oldukları bir çalışmada, tüketicilerin tutum, davranış, tüketim şekilleri ve ihtiyaçlarını karşılamak için ürün seçimleri konusunda diğer faktörlere göre kültürel faktörlerin ana belirleyici olduğunu ortaya koymuşlardır.

Literatürde tatil kararlarının alınmasına ve destinasyon seçiminin yapılmasına yönelik birçok çalışma bulunmaktadır. Ayrıca, az sayıda da olsa aile üyelerinin karar verme sürecindeki etkisinin ülkeler arasında farklılık gösterip göstermediğine yönelik araştırmalara da rastlanmaktadır. Bu konuda yapılan bir çalışmada, aile üyelerinin karar verme sürecindeki etkisinin ülkelere göre farklılık gösterdiği tespit edilmiştir (Green, Verhage ve Cunningham, 1981, s.72). Wang ve arkadaşları (2004) tatil kararlarının alınmasının eşler tarafından ortak verilen bir karar olduğunu, ancak anne ve babalar karar sürecinde hala baskın olsalar da son yıllarda çocukların da bu süreçte etkilerinin olduğunu ifade etmektedir. Çakıcı ve İyitoğlu'nun (2012) yapmış oldukları bir çalışmada, aile tatil kararının dinamik bir yapıya sahip olduğu, aile yapısının tatil kararlarında etkilerinin zamana ve ülkelere göre değişim gösterdiğini ortaya koymuşlardır.

Tüketicinin sosyalleşme sürecinde çeşitli kişi ya da gruplarla olan etkileşimleri, onların tüketim davranışlarının şekillenmesinde önemli bir rol oynamaktadır (Moschis ve Churchill, 1978, s.599-609). Bu noktada, referans gruplarının 
tüketim davranışına etkisi ön plana çıkmaktadır. Referans grupları, normatif ve karşılaştırmalı referans grupları olmak üzere iki alt grupta ele alınmaktadır (Funk, Alexandris ve McDonald, 2008). Bunlardan normatif referans grupları, anne/baba, iş/okul, öğretmenler gibi doğrudan etkileşimde bulunulan ve gereksinim duyulan her türlü bilgi ve becerilerin elde edildiği kişiler olarak değerlendirilmektedir. Karşılaştırmalı referans grupları ise kişisel ya da sosyal olarak daha uzak ve bilinilirliği yüksek, adeta ilham kaynağı olan ve başarı standartlarına ulaşıımak istenen kişilerden oluşmaktadır. Bunlara örnek olarak, ünlü sanatçılar, başarılı sporcular gösterilebilir (Bristol ve Mangleburg, 2005; Haroon ve Ul-Haq, 2015; Makgosa ve Mohube, 2007; Martin ve Bush, 2000; Subramanian ve Subramanian, 1995). Run, Butt ve Nee (2010) gerçekleştirdikleri bir çalışmada 19-25 yaş aralığındaki kişilerin satın alma niyetlerinde ve davranışlarında ilham kaynağı olarak gördükleri ünlüler ile anne/babalarının etkisini tespit etmiştir. Eskiler, Küçükibiş ve Soyer'in (2016) çalışmalarında, ünlü sporcuları rol model alma, marka duyarlıığı ve satın alma niyeti arasında anlamlı bir ilişki olduğu tespit edilmiştir. Bunların yanında, Türkiye'de Ayvalık, Çeşme ve Bodrum gibi deniz-kum-güneş destinasyonlarının tercih edilmesinde, popüler kişilerin etkisi bilinen bir gerçektir. Benzer şekilde, Kapadokya destinasyonunun popüler hale gelmesinde, o bölgede çekilen televizyon dizilerinin ve sinema filmlerinin etkisi yadsınamaz.

Yukarıda anlatılan aile ve referans grupları gibi sosyal faktörler ile kültürel faktörlerin tüketici davranışları üzerindeki etkilerini belirlemeye yönelik çalışmalardan ve farklı ülkelerden herhangi bir destinasyonu ziyaret için gelen turistlerin farklı sosyo-kültürel özelliklere sahip olacağı varsayımından hareketle bu araştırma özelinde aşağıdaki hipotez geliştirilmiştir.

H1: Turistlerin destinasyon seçiminde sosyo-kültürel faktörlerin etkisi ülkeye göre farklılaşmaktadır.

\subsection{Turizmde Farklı Motivasyonlar}

Genel bir ifadeyle motivasyon kavramı, insanları yerinden kaldırarak harekete geçiren, onların bir şeyler yapmalarını sağlayan sebepler olarak tanımlanabilir. Tüm davranışların temelinde bir ya da birden fazla motivasyon unsuru bulunmaktadır (Koç, 2015, s.243). Bu doğrultuda, tüketicinin turist olarak bir ülkeyi, bir bölgeyi ya da bir destinasyonu seçmesinin arkasında da çeşitli motivasyonel unsurların bulunduğu söylenebilir. Örneğin bir destinasyon, tarihi çekicilik, yemek kültürü, manzara, macera, heyecan, farklı kültürlerle tanışmak, mimari özellikler gibi unsurların biri ya da birkaçından dolayı tercih edebileceği gibi, insanların çoğunun gittiği bir yer olduğu için (moda olduğu için) de tercih edilebilir. Tüm bu unsurlar motivasyon kavramıyla ilişkilidir.

Farklı motivasyonel unsurların, bir turistin destinasyon seçimine olan etkisine yönelik az sayıdaki çalışmada, bu etkinin varlığı tespit edilmiştir. Bir çalışmada, seyahat deneyiminin algılanan değerinin belirleyicisi olan öncüller motivasyon, ilgilenim ve bilgi olarak ifade edilirken; sonuçların ise memnuniyet ve başkalarına tavsiye etme ya da yeniden satın alma şeklinde gerçekleşen gelecekteki niyet olduğu belirtilmiştir (Prebensen, Woo ve Uysal, 2014). Pizam ve arkadaşlarına göre (2002), turistlerin turistik ürün ve destinasyon seçimlerinin temelinde önemli bir motivasyon aracı olan heyecan arayışı bulunmaktadır (Koç, 2015, s.251). Benzer çalışmalarda, turist motivasyonunun bir destinasyonun algılanan değerini (Dumand ve Mattila 2005; Çelik Uğuz, Özbek ve Günalan, 2016) ve seyahat memnuniyetini (Yoon ve Uysal, 2005) etkilediği ortaya konmuştur.

Pazarlama literatürünün önde gelen isimlerinden Kotler (1997), pazar bölümlendirmenin coğrafik, demografik, psikografik ve davranışsal değişkenlere göre uygulanabileceğini ifade etmiştir. Kozak $(2010$, s.105) ise Kotler'in (1997) belirlemiş olduğu pazar bölümlendirme kriterlerine ilave olarak, turizm açısından, motivasyon, bilgi arama kaynağı, turizme katılım amacı gibi pazar bölümlendirme ölçütlerinin de mümkün olduğunu belirtmiştir (Çokişler ve Türker, 2015, s. 36-37). Clark'a göre (1990), tüketicilerin kültürleri, tüketici davranışlarına yön veren en önemli faktör olmakla birlikte, diğer faktörleri de şekillendiren önemli bir unsurdur. Bunlardan biri de motivasyon unsurudur.

Yukarıda özetlenen araştırma sonuçlarından ve farklı ülkelerden herhangi bir destinasyonu ziyaret için gelen turistlerin farklı motivasyonel unsurların etkisiyle hareket edebileceği varsayımından hareketle aşağıdaki hipotezin test edilmesine gereksinim duyulmuştur.

H2: Turistlerin destinasyon seçiminde motivasyonel unsurların etkisi ülkeye göre farklılaşmaktadır.

\section{YÖNTEM}

\subsection{Araştırmanın Amacı, Evreni ve Örneklemi}

Bu araştırmanın amacı, farklı sosyo-kültürel etkenlerle ve farklı motivasyonlarla bir turizm destinasyonunu ziyaret eden yerli ve yabancı turistler için farklı bir pazar bölümlendirmesine ihtiyaç olup olmadığını ortaya koymaktır. Farklı kültürlerden turistlerin ziyaret ettiği bilinen Kapadokya destinasyonu araştırmanın uygulama aşaması için uygun görülmüştür. Uygulama, bu destinasyonu ziyaret eden İngiliz, Alman ve Türk turistler arasından kolayda örnekleme yöntemiyle belirlenen 398 turist üzerinde 1 Temmuz-31 Ekim 2016 tarihleri arasında yüz yüze anket yöntemiyle gerçekleştirilmiştir. 


\subsection{Anket Formunun Tasarımı}

Araştırmanın saha uygulaması için, üç bölümden oluşan bir anket formu hazırlanmıştır. Anket formunun ilk bölümünde, cevaplayıııların demografik yapısını belirlemeye yönelik sorular yer almaktadır. İkinci bölümde, Kapadokya destinasyonunun tercih edilmesine neden olan sosyo-kültürel faktörleri; üçüncü bölümde ise bu tercihte etkili olan motivasyonel unsurları belirlemeye yönelik ifadeler bulunmaktadır. Sosyo-kültürel faktörler ve motivasyonel unsurlar 5'li Likert ölçeği ile hazırlanmış ifadelerden oluşmaktadır (1- Kesinlikle katılmıyorum; 2- Katılmıyorum; 3- Ne katılıyorum ne katılmıyorum; 4Katılıyorum; 5- Kesinlikle katılıyorum). Araştırmanın Sosyo-kültürel faktörlere yönelik ifadeleri Uğur ve Karaarslan (2016) tarafından yapılan çalışmadan alınmıştır. Motivasyonel unsurlara yönelik ifadeler ise Öter ve Özdoğan (2005) tarafından yapılan çalışmadan alınmış ve bu araştırmaya uygun hale getirilerek kullanılmıştır.

Araştırmanın anket formu Türkçe olarak hazırlanmış, İngilizce ve Almanca dilerine çevrilerek yabancı turistlerin cevaplayabileceği formlar oluşturulmuştur. Üç farklı dilde hazırlanan anket formları, Türk, Alman ve İngiliz turistlere uygulanmıştır.

\section{ARAŞTIRMANIN BULGULARI}

Bu bölümde araştırma verilerinin analizi sonucunda ortaya çıkan bulgulara yer verilmiştir. Verilerin analizinde frekans dağılımları kullanılmıştır. Araştırma hipotezleri, tek yönlü varyans analizi (ANOVA) ile test edilmiştir. Analizler SPSS 16.0 paket programı ile gerçekleştirilmiştir.

\subsection{Katılımcıların Demografik Özellikleri}

Tablo 1 incelendiğinde, araştırmaya katılan turistlerin büyük bir çoğunluğunun 35 yaş ve üzerinde olduğu ( $n=282 ; \% 70,9$ ); 294 kişinin $(\% 73,9)$ üniversite ve üzeri eğitim düzeyine sahip olduğu; \%51,5'inin ( $n=205)$ erkek katılımcılardan oluştuğu ve \%56'sının ( $n=223$ ) evli olduğu görülmektedir. Bunların yanı sıra, cevaplayıcıların büyük bir bölümünün 2001 TL (Euro / Pound) ve üzeri $(\% 77,9 ; n=310)$ aylık gelir düzeyine sahip olduğu da Tablo 1'de görülmektedir. Cevaplayıcıların hangi ülkelerden geldiğini ortaya koyan frekans dağıımları incelendiğinde, üç kategorinin katılımcı dağılımının birbirine oldukça yakın olduğu görülmektedir.

Tablo 1'de görülen soruların dışında, cevaplayıcılara Kapadokya ziyaretlerine ilişkin iki soru daha yöneltilmiştir. Buna göre, cevaplayıcıların “Kapadokya'ya kaç kişi ile birlikte geldiniz?" sorusuna verdikleri yanıtlar incelendiğinde ortalama değerin 4,5 kişi olduğu görülmüştür. Bu soruya cevaplayıcıların \%70,9'u 2 ila 7 kişi arasında bir değer ifade etmiştir. Diğer taraftan "Kapadokya'da kaç gece konaklayacaksınız?" sorusuna verilen cevapların ortalaması 5,45 gün olarak hesaplanmıştır. Cevaplayıcıların \%38,7'si (n=154) 5 günden az konaklayacağını ifade ederken; geriye kalan \%61,3’lük kesim ( $n=244) 5$ gün ya da daha fazla konaklayacağını belirtmiştir.

Tablo 1: Cevaplayıcıların Demografik Özellikleri

\begin{tabular}{|c|c|c|c|c|c|}
\hline \multicolumn{3}{|l|}{ YAŞ } & \multicolumn{3}{|l|}{ EĞiTiM } \\
\hline & $\mathrm{n}$ & $\%$ & & $\mathrm{n}$ & $\%$ \\
\hline $15-24$ & 34 & 8,5 & Lise & 73 & 18,3 \\
\hline $25-34$ & 82 & 20,6 & Üniversite & 197 & 49,5 \\
\hline $35-44$ & 114 & 28,6 & Master & 82 & 20,6 \\
\hline $45-54$ & 108 & 27,2 & Doktora & 15 & 3,8 \\
\hline 55 ve Üstü & 60 & 15,1 & Diğer & 31 & 7,8 \\
\hline Toplam & 398 & 100 & Toplam & 398 & 100 \\
\hline \multicolumn{3}{|l|}{ CINSIYYT } & \multicolumn{3}{|c|}{ MEDENI DURUM } \\
\hline Kadın & 193 & 48,5 & Evli & 223 & 56 \\
\hline Erkek & 205 & 51,5 & Bekâr & 175 & 44 \\
\hline Toplam & 398 & 100 & Toplam & 398 & 100 \\
\hline \multicolumn{3}{|l|}{ GELIR } & \multicolumn{3}{|c|}{ TURISTIN UYRUĞU } \\
\hline 2000 TL (Euro / Pound) ve Altı & 88 & 22,1 & İngiltere & 137 & 34,4 \\
\hline 2001-3000 TL (Euro / Pound) & 164 & 41,2 & Almanya & 132 & 33,2 \\
\hline 3001 TL (Euro / Pound) ve Üstü & 146 & 36,7 & Türkiye & 129 & 32,4 \\
\hline Toplam & 398 & 100 & Toplam & 398 & 100 \\
\hline
\end{tabular}




\subsection{Hipotezlerin Testi}

Tablo 2'de cevaplayıcıların Kapadokya'yı tercih etmelerine neden olan sosyo-kültürel faktörlerin etkisinin geldikleri ülkeye göre farklılık gösterip göstermediğini ortaya koymaya yönelik olarak yapılan Tek Yönlü Varyans Analizi (ANOVA) sonuçları görülmektedir. Buna göre, hem İngiltere hem de Almanya'dan Kapadokya'ya gelen yabancı turistlerin aile bireylerinin tavsiyelerini yerli turistlere göre daha fazla önemsedikleri görülmektedir. Arkadaş tavsiyelerine verilen önem ise İngiliz turistlerde diğerlerine göre daha yüksektir. Değer verilen kişilerin tavsiyelerine verilen önem üç ayrı grupta istatistiksel olarak farklılaşmamaktadır. Örnek alınan ve özenilen kişilerin tavsiyelerinin etkisi ise Türk ve Alman turistlerde İngiliz turistlere göre daha yüksektir. Kültürel nedenlerin etkisi İngiliz turistlerde diğerlerine göre oldukça yüksek bulunmuştur. Bu bulgulardan hareketle, "değer verilen kişilerin tavsiyesi" dışında kalan dört sosyo-kültürel faktör açısından H1 hipotezinin desteklendiği söylenebilir.

Araştırma bulguları, yerli turistlerin Kapadokya'yı ziyaretine en çok etki eden faktörlerin değer verilen kişilerin, örnek alınan ve özenilen kişilerin ve arkadaşların tavsiyeleri olduğunu gösterirken; İngiliz turistlerin ziyaretine en çok etki eden sosyokültürel faktörler sırasıyla kültürel nedenler, aile ve arkadaş tavsiyeleri olarak tespit edilmiştir. Alman turistlerin tercihlerini en çok etkileyen sosyo-kültürel faktörler ise sırasıyla aile, örnek alınan ve özenilen kişiler ve değer verilen kişilerin tavsiyeleridir.

Tablo 2'deki bulgularda görüldüğü gibi, aile, arkadaş ve örnek alınan ve özenilen kişilerin tavsiyesi ile kültürel nedenler Türk, Alman ve İngiliz turistlerde istatistiksel olarak anlamlı bir biçimde değişmektedir. Ancak bu farklılıkların hangi ülkeden gelen turistler arasında gerçekleştiğini daha derinlemesine inceleyebilmek için ikili karşılaştırmalar yapılmasında yarar görülmüştür.

Tablo 2: Cevaplayıcıların Kapadokya'yı Tercih Etmelerine Neden Olan Sosyo-Kültürel Faktörlerin Etkisinin Geldikleri Ülkeye Göre Değişip Değişmediğini Ortaya Koymaya Yönelik ANOVA Sonuçları

\begin{tabular}{|c|c|c|c|c|c|c|}
\hline Tercih Nedenleri & Ülkeler & $\mathrm{n}$ & Ortalama & Standart Sapma & $\mathrm{F}$ & $\mathrm{p}$ \\
\hline \multirow{4}{*}{$\begin{array}{l}\text { Aile Bireylerinin } \\
\text { Tavsiyesi }\end{array}$} & Ingiltere & 137 & 3,92 & 0,900 & \multirow{4}{*}{21,877} & \multirow{4}{*}{0,001} \\
\hline & Almanya & 132 & 3,90 & 0,846 & & \\
\hline & Türkiye & 129 & 3,25 & 1,053 & & \\
\hline & Toplam & 398 & 3,70 & 0,984 & & \\
\hline \multirow{4}{*}{ Arkadaşların Tavsiyesi } & Ingiltere & 137 & 3,67 & 0,940 & \multirow{4}{*}{4,645} & \multirow{4}{*}{0,010} \\
\hline & Almanya & 132 & 3,36 & 1,057 & & \\
\hline & Türkiye & 129 & 3,33 & 1,056 & & \\
\hline & Toplam & 398 & 3,46 & 1,027 & & \\
\hline \multirow{4}{*}{$\begin{array}{c}\text { Değer Verilen Kişilerin } \\
\text { Tavsiyesi }\end{array}$} & Ingiltere & 137 & 3,58 & 0,945 & \multirow{4}{*}{0,215} & \multirow{4}{*}{0,807} \\
\hline & Almanya & 132 & 3,57 & 0,967 & & \\
\hline & Türkiye & 129 & 3,50 & 1,039 & & \\
\hline & Toplam & 398 & 3,55 & 0,982 & & \\
\hline \multirow{4}{*}{$\begin{array}{c}\text { Örnek Alınan ve } \\
\text { Özenilen Kişilerin } \\
\text { Tavsiyesi }\end{array}$} & İngiltere & 137 & 3,26 & 1,015 & \multirow{4}{*}{6,222} & \multirow{4}{*}{0,002} \\
\hline & Almanya & 132 & 3,67 & 1,008 & & \\
\hline & Türkiye & 129 & 3,50 & 0,911 & & \\
\hline & Toplam & 398 & 3,47 & 0,993 & & \\
\hline \multirow{4}{*}{ Kültürel Nedenler } & Ingiltere & 137 & 4,17 & 0,743 & \multirow{4}{*}{43,755} & \multirow{4}{*}{0,001} \\
\hline & Almanya & 132 & 3,31 & 1,027 & & \\
\hline & Türkiye & 129 & 3,19 & 1,021 & & \\
\hline & Toplam & 398 & 3,57 & 1,033 & & \\
\hline
\end{tabular}

Scheffe tekniğiyle Post-Hoc testleri gerçekleştirilerek yapılan ikili karşılaştırmaların test sonuçları ve aritmetik ortalamaları değerlendirildiğinde, Kapadokya destinasyonunun tercihinde aile bireylerinin etkisinin İngiliz ve Alman turistlerde farklı olmadığı (sırasıyla 3,92 ve 3,90; $p=0,987$ ); ancak Türk turistlerle $(3,25)$ hem Ingilizlerin $(3,92, p=0,001)$ hem de Almanların $(3,90, p=0,001)$ anlamlı bir şekilde farklılaştığı bulunmuştur. Arkadaşların tavsiyesi ikili karşılaştırmalarla incelendiğinde, Ingilizlerle $(3,67)$ hem Almanların $(3,36, p=0,041)$ hem de Türklerin $(3,33, p=0,026)$ farklılaştığı; ancak Almanlarla Türklerin farklılaşmadığı $(p=0,984)$ görülmüştür. Örnek alınan ve özenilen kişilerin tavsiyesi ikili karşılaştırmalarla değerlendirildiğinde, 
İngilizlerle $(3,26)$ Almanlar arasında anlamlı bir fark bulunmuş $(3,67, p=0,002)$, ancak Türklerle $(3,50)$ İngilizler $(p=0,120)$ ve Türklerle Almanlar $(p=0,374)$ arasında farklılık ortaya çıkmamıştır. Araştırma kapsamındaki turistlerin Kapadokya'yı tercih etmelerinde kültürel nedenlerin etkisi incelendiğinde, İngilizlerle $(4,17)$ Almanların $(3,31, p=0,001)$ ve İngilizlerle Türklerin $(3,19, p=0,001)$ anlamlı bir biçimde birbirinden farklılaştığı; Türklerle Almanlar arasında ise kültürel nedenlerin etkisi bakımından bir fark olmadığı $(p=0,562)$ tespit edilmiştir. Bu bulgular, Kapadokya destinasyonunu ziyaret eden turistler arasında sosyo-kültürel açıdan bir pazar bölümlendirmesi yapma fikrinin değerlendirilebileceğini ortaya koymaktadır.

Tablo 3'te cevaplayıcıların Kapadokya'yı tercih etmelerine neden olan motivasyonel unsurların geldikleri ülkeye göre farklılık gösterip göstermediğini ortaya koymaya yönelik olarak yapılan Tek Yönlü Varyans Analizi (ANOVA) sonuçları görülmektedir. Aritmetik ortalamalar incelendiğinde, İngiliz turistlerin Kapadokya'yı tercih etmesinde etkili olan motivasyonel unsurlar arasında en çok "görülecek eşsiz yerler", "tarihi mimari" , "müzeler ve kültürel çekicilikler" "çok kültürlü bölge" ve "kültürü farklı bölge" unsurlarının öne çıktığı görülmüştür. Alman turistleri en çok motive eden unsurlar, sırasıyla "yerel mutfak", "hareketli ortam", "festivaller ve aktiviteler", "görülecek eşsiz yerler" ve "moda olduğu için gidilen yer" olarak tespit edilmiştir. Türk turistleri daha yüksek düzeyde motive eden unsurlar ise, "moda olduğu için gidilen yer", "festivaller ve aktiviteler", "görülecek eşsiz yerler", "hareketli ortam" ve "müzeler ve kültürel çekicilikler" şeklinde sıralanmaktadır.

Tablo 3: Cevaplayıcıların Kapadokya'yı Tercih Etmelerine Neden Olan Motivasyonel Unsurların Etkisinin Geldikleri Ülkeye Göre Değişip Değişmediğini Ortaya Koymaya Yönelik ANOVA Sonuçları

\begin{tabular}{|c|c|c|c|c|c|c|}
\hline Tercih Nedenleri & Ülkeler & $n$ & Ortalama & Standart Sapma & $\mathrm{F}$ & $\mathrm{p}$ \\
\hline \multirow{4}{*}{ Görülecek eşsiz yerler } & Ingiltere & 137 & 4,48 & 0,502 & \multirow{4}{*}{42,901} & \multirow{4}{*}{0,001} \\
\hline & Almanya & 132 & 3,63 & 0,906 & & \\
\hline & Türkiye & 129 & 3,88 & 0,872 & & \\
\hline & Toplam & 398 & 4,01 & 0,856 & & \\
\hline \multirow{4}{*}{ Tarihi mimari } & Ingiltere & 137 & 4,39 & 0,49 & \multirow{4}{*}{78,967} & \multirow{4}{*}{0,001} \\
\hline & Almanya & 132 & 3,35 & 1,026 & & \\
\hline & Türkiye & 129 & 3,19 & 0,953 & & \\
\hline & Toplam & 398 & 3,66 & 1,006 & & \\
\hline \multirow{4}{*}{$\begin{array}{l}\text { Müzeler ve kültürel } \\
\text { çekicilikler }\end{array}$} & İngiltere & 137 & 4,38 & 0,502 & \multirow{4}{*}{75,956} & \multirow{4}{*}{0,001} \\
\hline & Almanya & 132 & 3,10 & 1,025 & & \\
\hline & Türkiye & 129 & 3,68 & 0,952 & & \\
\hline & Toplam & 398 & 3,73 & 1,002 & & \\
\hline \multirow{4}{*}{$\begin{array}{l}\text { Festivaller ve } \\
\text { aktiviteler }\end{array}$} & Ingiltere & 137 & 3,15 & 0,923 & \multirow{4}{*}{27,642} & \multirow{4}{*}{0,001} \\
\hline & Almanya & 132 & 3,64 & 0,943 & & \\
\hline & Türkiye & 129 & 3,96 & 0,804 & & \\
\hline & Toplam & 398 & 3,58 & 0,951 & & \\
\hline \multirow{4}{*}{ Gelenek ve görenekler } & İngiltere & 137 & 3,85 & 0,794 & \multirow{4}{*}{13,485} & \multirow{4}{*}{0,001} \\
\hline & Almanya & 132 & 3,27 & 1,049 & & \\
\hline & Türkiye & 129 & 3,44 & 0,943 & & \\
\hline & Toplam & 398 & 3,53 & 0,962 & & \\
\hline \multirow{4}{*}{ Yerel mutfak } & Ingiltere & 137 & 3,10 & 0,949 & \multirow{4}{*}{20,648} & \multirow{4}{*}{0,001} \\
\hline & Almanya & 132 & 3,78 & 0,944 & & \\
\hline & Türkiye & 129 & 3,67 & 0,903 & & \\
\hline & Toplam & 398 & 3,51 & 0,978 & & \\
\hline \multirow{4}{*}{$\begin{array}{l}\text { Misafirperver yerel } \\
\text { halk }\end{array}$} & Ingiltere & 137 & 2,81 & 0,989 & \multirow{4}{*}{15,178} & \multirow{4}{*}{0,001} \\
\hline & Almanya & 132 & 3,48 & 1,101 & & \\
\hline & Türkiye & 129 & 3,28 & 0,968 & & \\
\hline & Toplam & 398 & 3,18 & 1,057 & & \\
\hline \multirow{4}{*}{ Hareketli ortam } & Ingiltere & 137 & 3,03 & 1,084 & \multirow{4}{*}{25,224} & \multirow{4}{*}{0,001} \\
\hline & Almanya & 132 & 3,71 & 0,977 & & \\
\hline & Türkiye & 129 & 3,83 & 0,92 & & \\
\hline & Toplam & 398 & 3,52 & 1,057 & & \\
\hline \multirow{4}{*}{ Dil çeşitliliği } & Ingiltere & 137 & 3,22 & 1,062 & \multirow{4}{*}{0,457} & \multirow{4}{*}{0,634} \\
\hline & Almanya & 132 & 3,32 & 1,006 & & \\
\hline & Türkiye & 129 & 3,20 & 1,135 & & \\
\hline & Toplam & 398 & 3,25 & 1,067 & & \\
\hline Kültürü farklı bölge & İngiltere & 137 & 4,17 & 0,743 & 48,468 & 0,001 \\
\hline
\end{tabular}




\begin{tabular}{|c|c|c|c|c|c|c|}
\hline & Almanya & 132 & 3,27 & 0,964 & & \\
\hline & Türkiye & 129 & 3,26 & 0,904 & & \\
\hline & Toplam & 398 & 3,57 & 0,972 & & \\
\hline \multirow{4}{*}{ Çok kültürlü bölge } & İngiltere & 137 & 4,32 & 0,706 & \multirow{4}{*}{65,659} & \multirow{4}{*}{0,001} \\
\hline & Almanya & 132 & 3,12 & 0,957 & & \\
\hline & Türkiye & 129 & 3,55 & 0,935 & & \\
\hline & Toplam & 398 & 3,67 & 1,003 & & \\
\hline \multirow{4}{*}{$\begin{array}{l}\text { Moda olduğu için } \\
\text { gidilen yer }\end{array}$} & Ingiltere & 137 & 2,72 & 0,983 & \multirow{4}{*}{62,456} & \multirow{4}{*}{0,001} \\
\hline & Almanya & 132 & 3,51 & 1,015 & & \\
\hline & Türkiye & 129 & 4,00 & 0,81 & & \\
\hline & Toplam & 398 & 3,4 & 1,078 & & \\
\hline
\end{tabular}

Tablo 3'teki bulgular Kapadokya'yı ziyaret eden İngiliz, Alman ve Türk turistlerin bu tercihlerine etki eden motivasyonel unsurların "dil çeşitliliği" dışında kalan tüm unsurlarda farklılaştığını göstermektedir. Dolayısıyla H2 hipotezi bu unsur dışında desteklenmiştir. Bu farklııkların derinlemesine incelenebilmesi için Scheffe tekniğiyle Post-Hoc testleri gerçekleştirilerek ikili karşılaştırmalar yapılmıştır.

Post-Hoc testi sonuçları değerlendirildiğinde, "görülecek eşsiz yerler", "müzeler ve kültürel çekicilikler", "festivaller ve aktiviteler", "çok kültürlü bölge" ve "moda olduğu için gidilen yer" unsurlarının ülkeler arasındaki tüm ikili karşılaştırmalarda anlamlı bir şekilde farklılaştığı tespit edilmiştir. Yani bu unsurlar açısından İngiliz, Alman ve yerli turistler için farklı pazar bölümlendirmesi yapmak uygun görünmektedir. Diğer taraftan, "tarihi mimari", "gelenek ve görenekler", "yerel mutfak", "misafirperver yerel halk", "hareketli ortam" ve "kültürü farklı bölge" motivasyon boyutları İngiliz ve Alman turistlerle İngiliz ve Türk turistler arasında farklılaşırken; Alman ve Türk turistlerde bu boyutlarda anlamlı bir fark bulunamamıştır. Bu bulgular, Alman ve Türk turistlerin bu motivasyon unsurları açısından benzerlik gösterdiği, İngiliz turistlerin ise Alman ve Türk turistlerden farklılaştığı şeklinde yorumlanabilir. Bu unsurlar açısından bakıldığında, İngiliz turistler ayrı bir pazar bölümü olarak değerlendirilebilir.

\section{SONUÇ VE ÖNERILER}

Kapadokya destinasyonu özelinde gerçekleştirilen bu araştırmanın temel amacı, farklı sosyo-kültürel etkenlerle ve farklı motivasyonlarla bir turizm destinasyonunu ziyaret eden yerli ve yabancı turistler için farklı bir pazar bölümlendirmesine ihtiyaç olup olmadığını ortaya koymaktır. Bu amaca ulaşmak için İngiliz, Alman ve Türk turistlerden oluşan bir kitlenin Kapadokya destinasyonunu tercih etmesinde çeşitli sosyo-kültürel faktörler ve motivasyonel unsurlardan hangi düzeyde etkilendiği ölçülmeye çalışılmıştır. Araştırma sonuçları, genel olarak turistlerin Kapadokya'yı tercih etmede etkilendiği sosyokültürel faktörlerin ve motivasyonel unsurların ülkelere göre farklılaştığını ortaya koymaktadır. Bu nedenle araştırma kapsamında kurgulanan iki hipotez desteklenmiştir.

Destinasyon tercihinde sosyo-kültürel faktörlerin etkisinin ülkelere göre değişip değişmediğini ortaya koymaya yönelik olarak tasarlanan $\mathrm{H} 1$ hipotezi aile bireylerinin tavsiyesi, arkadaşların tavsiyesi, örnek alınan ve özenilen kişilerin tavsiyesi ve kültürel nedenler alt başlıklarında desteklenmiştir. Aile bireylerinin etkisi Türk turistlerde İngiliz ve Alman turistlere göre oldukça düşük düzeyde gerçekleşmiştir. Arkadaşların tavsiyesi ise, İngiliz turistlerde yüksek bir düzeyde etkili olurken, Alman ve Türk turistlerde nispeten düşük bir etkiye sahiptir. Örnek alınan ve özenilen kişilerin tavsiyesi Alman turistlerde yüksek düzeyde etkili olurken, İngiliz turistlerde göreceli olarak düşük çıkmıştır. Kültürel nedenler incelendiğinde ise, İngilizlerin bu unsurdan oldukça yüksek düzeyde etkilendiği, Alman ve Türk turistlerde bu etkinin nispeten düşük kaldığı görülmüştür. Değer verilen kişilerin etkisi, söz konusu üç grup açısından istatistikî olarak farklılaşmamıştır.

Araştırma özelinde sosyo-kültürel etkenlerin destinasyon tercihindeki etkisi ülke bazında değerlendirildiğinde, İngiliz turistlerin ailelerinden, arkadaşlarından ve kültürel etkenlerden yüksek düzeyde etkilendiği görülmektedir. Alman turistler ise, aileleri ile örnek alınan ve özenilen kişilerden yüksek düzeyde etkilenmektedir. Türk turistlerin sosyo-kültürel faktörlerden İngiliz ve Alman turistler kadar etkilenmediği söylenebilir. Bu sonuçlardan hareketle, Kapadokya destinasyonundaki kamu yöneticilerine, yerel yönetimlere ve işletmecilere farklı ülkelerden gelen turistlerin Kapadokya tercihlerinde hangi sosyo-kültürel faktörlerden etkilendiklerini incelemeleri ve eğer bu turistlerin oluşturduğu pazar yeterli büyüklükteyse, sosyo-kültürel etkenlere göre bir bölümlendirmeye gitmeleri önerisinde bulunulabilir. Bu bağlamda, örneğin İngiliz turistler için tanıtımlarda Kapadokya'nın kültürel dokusuna vurgu yapılması onları etkileyebilecekken, Alman turistleri çekmek için Almanya'nın sevilen sanatçılarının tanıtımlarda kullanılması faydalı olabilir.

Destinasyon tercihinde motivasyonel unsurların etkisinin ülkelere göre değişip değişmediğini ortaya koymaya yönelik olarak tasarlanan H2 hipotezi, "görülecek eşsiz yerler", "tarihi mimari", "müzeler ve kültürel çekicilikler", "festivaller ve aktiviteler", "gelenek ve görenekler", "yerel mutfak", "misafirperver yerel halk", "hareketli ortam”, "kültürü farklı bölge", "çok kültürlü bölge" ve "moda olduğu için gidilen yer" alt unsurlarında desteklenirken, "dil çeşitliliği" alt unsurunda desteklenmemiştir. 
Özellikle "görülecek eşsiz yerler", "müzeler ve kültürel çekicilikler", "festivaller ve aktiviteler", "çok kültürlü bölge” ve "moda olduğu için gidilen yer" alt unsurlarının motivasyonel etkisi İngiliz, Alman ve Türk turistlerde tamamıyla farklılaşmaktadır.

İngiliz turistlerin Kapadokya'yı tercih etmesinde etkili olan motivasyonel unsurlar arasında en çok "görülecek eşsiz yerler", "tarihi mimari" , "müzeler ve kültürel çekicilikler" "çok kültürlü bölge" ve "kültürü farklı bölge" unsurlarının öne çıktığı görülmüştür. Bu noktada, sosyo-kültürel etkenlerde de değinildiği gibi, İngilizlerin bu destinasyonu tercihinde kültürel etkenlerin etkisi ciddi düzeyde yüksektir. Dolayısıyla, İngiliz turistleri ayrı bir pazar olarak ele alıp, onları kültürel unsurlarla destinasyona çekmeye çalışmak faydalı sonuçlar verebilecektir. Alman turistleri en çok motive eden unsurlar, sırasıyla "yerel mutfak", "hareketli ortam", "festivaller ve aktiviteler", "görülecek eşsiz yerler" ve "moda olduğu için gidilen yer" olarak tespit edilmiştir. Bu sonuçlar, Alman turistlerin İngilizlerden farklı motivasyonlarla Kapadokya'yı tercih ettiğini göstermektedir. Bu doğrultuda, Alman turistleri de farklı bir pazar olarak ele almak ve derinlemesine incelemek faydalı olacaktır. Türk turistleri daha yüksek düzeyde motive eden unsurlar ise, "moda olduğu için gidilen yer", "festivaller ve aktiviteler", "görülecek eşsiz yerler", "hareketli ortam" ve "müzeler ve kültürel çekicilikler" şeklinde sıralanmaktadır. Bu sıralama Alman turistlerle ciddi bir benzerlik göstermektedir. Bu nedenle, Alman ve Türk turistleri aynı Pazar bölümünde ele alma düşüncesi değerlendirilebilir. Diğer taraftan, Türk turistlerin bir destinasyonu moda olduğu için tercih ettiği çoğu zaman gözlemlenen bir olgudur. Örneğin, Bursa iline bağlı Cumalıkızık köyü, bölgede çekilen bir televizyon dizisinden sonra popüler hale gelmiştir. Dizi 2005 yılında sona ermesine rağmen, halen çok sayıda yerli turist bu köyü ziyaret etmeye devam etmektedir. Bu doğrultuda, Kapadokya bölgesinin popülaritesini korumaya devam etmesi, Türk turistlerin bu bölgeyi tercih etmesinde etkili olabilecektir.

Yukarıda ifade edilen sonuçlar ve sonuçlara yönelik yapılan pazar bölümlendirme önerileri, pazarın yeterli büyüklükte olup olmadığı belirlenerek dikkate alınmalıdır. Zira bir turist kitlesinin bir destinasyonu tercih etmede diğerlerinden farklı sosyokültürel faktörlere ve motivasyonel unsurlara sahip olması, doğrudan o kitlenin ayrı bir pazar bölümü oluşturacağı anlamına gelmez. Bunu söyleyebilmek için, bu turist kitlesinin destinasyon için önemli bir büyüklüğe sahip olması gerekmektedir.

Bu araştırma, Kapadokya destinasyonunu ziyaret eden İngiliz, Alman ve Türk turistler üzerinde gerçekleştirilmiştir. Bu bağlamda, araştırma bulguları sadece bu kitle ve destinasyona yönelik sonuçlar ortaya koymaktadır. Dolayısıyla, araştırma sonuçlarının genellenmesi doğru değildir. Bu konuda araştırma yapacak akademisyenlere, sosyo-kültürel faktörlerin ve motivasyonel unsurların destinasyon tercihi üzerindeki etkisini farklı bir destinasyonda incelemeleri önerisinde bulunulabilir. Ayrıca, destinasyon tercihinde etkili olabilecek ilgilenim faktörü de bu tarz bir araştırmada incelenebilecek bir değişkendir.

\section{KAYNAKLAR}

Akat, Ö. (2003). Uluslararası Pazarlama Karması ve Yönetimi. (4). Ekin Kitapevi: Bursa.

Bristol, T., Mangleburg, T.F. (2005). Not telling the whole story: Teen deception in purchasing. Journal of the Academy of Marketing Science, vol.33, no.1, p. 79-95.

Clark, T. (1990). International marketing and national character: A review and proposal for an integrative theory. Journal of Marketing, no.54, p. 66-79.

Çakııı, C., İyitoğlu, V. (2012). Tatil kararlarında aile üyelerinin rolü: Antalya ilinde tatil yapan aileler üzerine bir araştırma. Çukurova Üniversitesi Sosyal Bilimler Enstitüsü Dergisi, vol.21, no.1, p. 117-134.

Çelik Uğuz, S., Özbek, V., Günalan, M. (2016). Motivation and Involvement as Antecedents of the Perceived Value of the Festival Experience: A Study on Burhaniye Bicycle Festival. Global Issues and Trends in Tourism. (1). St. Kliment Ohridski University Press: Sofia.

Çokişler, N., Türker, A. (2015). Doğu karadeniz bölgesinin yerli turist profili ve pazar bölümlendirmede kullanımı. Karadeniz Araştırmaları, no.44, p. 33-57.

Demir, Ş.Ş. (2010). Çekici faktörlerin destinasyon seçimine etkisi: Dalyan örneği. Ege Akademik Bakış, vol.10, no.3, p. 1041-1054.

Dumand, T., Mattila, A.S. (2005). The role of affective factors on perceived cruise vacation value. Tourism Management, vol.26, no.3, p. 311-23.

Eskiler. E., Küçükibiş, F., Soyer, F. (2016). Genç tüketicilerin satın alma davranışları üzerine rol model etkisi: Marka duyarlılığı aracılık rolü. International Congresses on Education, Sarajevo/Bosnia and Herzegovina.

Funk, D., Alexandris, K., McDonald, H. (2008). Consumer Behaviour in Sport and Events. Routledge: New York.

Gnoth, J. (1997). Tourism motivation and expectation formation. Annals of Tourism Researh, vol.24, no.2, p. $283-304$.

Green, R.T., Verhage, B.J., Cunningham, I.C.M. (1981). Household purchasing decision: How do american and dutch consumer differ?. European Journal of Marketing, vol. 15, no.1, p. 68-77.

Haroon, M.Z., Mirza Amin ul-Haq, N. (2015). Impact of role model on behaviour and purchase Intentions among youngsters: Empirical evidence from Karachi, Pakistan. Journal of Management Sciences, vol.2, no.2, p. 242-254. 
Hayta, A.B. (2008). Turizm pazarlamasında tüketici satın alma süreci ve karşılaşılan sorunlar. Kastamonu Eğitim Dergisi, vol.16, no.1, p. 3148.

Iso-Ahola, S.E., Allen, J. (1982). The dynamics of leisure motivation: The effects of outcome on leisure needs. Research Quarterly for Exercise and Sport, no.53, p. 141-149.

Klenosky, D.B. (2002). The pull of tourism destinations: A means-end investigation. Journal Of Travel Research, vol.40, no.4, p. 385-395.

Koç, E. (2015). Tüketici Davranışı ve Pazarlama Stratejileri Global ve Yerel Yaklaşım. (6). Seçkin Yayıncılık: Ankara.

Kotler, P., Bowen, J., Makens, J. (2003). Marketing for Hospitality and Tourism. (3). Prentice Hall: New Jersey.

Kotler, P.,Keller, K.L. (2006). Marketing Management. (12). Pearson Education Inc.: New Jersey.

Lee, C. (2000). A comparative study of caucasian and asian visitors to a cultural expo in an asian setting. Tourism Management, vol.21, no.2, p. 169-176.

Makgosa, R., Mohube, K. (2007). Peer influence on young adults' product purchase decisions. African Journal of Consumer Marketing, vol.1, no.3, p. 64-71.

Martin, C., Bush, A. (2000). Do role models influence teenagers' purchase intentions and behavior?. Journal of Consumer Marketing, vol.17, no.5, p. 441-453.

Moschis, G.P., Churchill, Jr, G.A. (1978). Consumer socialition: A theoretical and empirical analysis. Journal of Marketing, no.15, p. 599-609.

Mucuk, İ. (2010). Pazarlama İlkeleri. (18). Türkmen Kitabevi: İstanbul.

Nacar, R., Uray, N. (2014). Küresel tüketici kültürü kavramıyla birlikte değişen pazar bölümlendirme yaklaşımları: Uluslararası pazarlama literatürüne bakıs. Yalova Sosyal Bilimler Dergisi, vol.5, no.8, p. 23-50.

Nakip, M., Varinli, I., Gülmez, M. (2012). Güncel Pazarlama Yönetimi. Detay Yayıncılık: Ankara.

Odabaşı, Y., Barış, G. (2010). Türetici Davranışı. (9). Mediacat Yayınları: İstanbul.

Öter, Z., Özdoğan, O.N. (2005). Kültür amaçıı seyahat eden turistlerde destinasyon imajı: Selçuk-efes örneği. Anatolia: Turizm Araştırmaları Dergisi, vol.16, no.2, p.127-138.

Penaloza, L.N., Gilly, M.C. (1999). Marketer acculturation: The changer and the changed. Journal of Marketing, vol.63, no.3, p. 84-104.

Prebensen, N.K., Woo, E., Uysal, M.S. (2014). Experience value: Antecedents and consequences. Current Issues in Tourism, vol.17, no.10, p. 910-928.

Run, E.C., Butt, M., Nee, C.Y. (2010). The influnce of role models on young adults purchase. Jurnal Kemanusiaan, no.15, p. 70-81.

Subramanian, S., Subramanian, A. (1995). Reference group influence on innovation adoption behaviour: Incorporating comparative and normative referents. European Advances in Consumer Research, no.2, p.14-18.

Tayfun, A., Yıldırım, M. (2010). Turistlerin tüketim davranışları kültüre/milliyete göre farklılık gösterir mi? Alman ve rus turistler üzerine bir araştırma. İşletme Araştırmaları Dergisi, vol.2, no.2, p. 43-64.

Tek, Ö.B. (1997). Pazarlama İlkeleri, Global Yönetimsel Yaklaşım Türkiye Uygulamaları. (7). Cem Ofset: İzmir.

Uğur, i., Karaarslan, M.H. (2016). Destinasyon seçiminde fikir gruplarının etkisi: Safranbolu üzerine bir araştırma. Namık Kemal Üniversitesi Sosyal Bilimler Metinleri, no.1, p. 59-70.

Uysal, M., Li, X. (2008). Trends and Critical Issues in Festival \& Event Motivation. In A. Aktas, M. Kesgin, E. Cengiz ve E. Yenidip (eds.). International Cultural and Event Tourism: Issues and Debates, Detay Yayıncilık: Ankara.

Wang, K.C., Hsieh, A.T., Yeh, Y.C., Tsai, C.W. (2004). Tourist group holiday decision-making and behaviour: The Influence of children. Tourism Management, vol.25, no.2, p. 183-194.

Yoon, Y., Uysal, M. (2005). An examination of the effects of motivation and satisfaction on destination loyalty: A structural model. Tourism Management, no.26, p. 45-56.

Yükselen, C. (2012). Pazarlama, ilkeler-yönetim-örnek olaylar. (9). Detay Yayıncılık: Ankara. 